pISSN : $2301-8968$

JEKT $14[1]: 1-10$

eISSN : $2303-0186$

\title{
Can Cryptocurrency, Gold and Bonds Serve as Safe Haven for the Indonesian Capital Market?
}

\author{
Paulus Hartono \\ Robiyanto \\ Universitas Kristen Satya Wacana
}

\begin{abstract}
Penelitian ini bertujuan menguji potensi cryptocurrency, emas dan obligasi sebagai safe haven terhadap pasar modal Indonesia. Data yang dipergunakan dalam penelitian ini adalah data penutupan harian cryptocurrency, emas (GOLDIDR) dan Indonesia Government Bond Index (IGBI) selama periode Agustus 2015 hingga Desember 2018 yang diperoleh dari Investing, Yahoo Finance, dan Spindices. Analisis data menggunakan Ordinary Least Square (OLS) dan Quantile Regression (QREG). Hasil penelitian menemukan bahwa ethereum dapat menjadi safe haven. Sementara bitcoin, ripple, emas, dan Indonesia Government Bond Index (IGBI) tidak dapat menjadi safe haven bagi pasar modal Indonesia.
\end{abstract}

Keywords: safe haven, cryptocurrency, gold, Indonesia Government Bond Index (IGBI). JEL classification: G10, G11, G15.

\section{Can Cryptocurrency, Gold and Bonds Play a Role as a Safe Haven for the Indonesian Capital Market?}

\author{
Paulus Hartono \\ Robiyanto
}

\begin{abstract}
The purpose of this research to test the cryptocurrency, gold and bonds as safe haven assets to Indonesian capital market. The data used in this study is the daily closing data of cryptocurrency, gold (GOLDIDR) and the Indonesian Government Bond Index (IGBI) during the period on August 2015 to December 2018 obtained from Investing, Yahoo Finance, and Spindices. The analysis of the data is used Ordinary Least Square (OLS) and Quantile Regression (QREG). The results found that ethereum can be a safe haven. While bitcoin, ripple, gold, and the Indonesian Government Bond Index (IGBI) cannot be a safe haven for the Indonesian capital market.

Keywords: safe haven, cryptocurrency, gold, Indonesia Government Bond Index (IGBI). JEL Classifications: G10, G11, G15

\section{PRELIMINARY}

The Indonesian capital market is an attractive place for investors to invest, but

on the other hand, the uncertainty in the capital market has made investors refrain from investing in the capital market. This
\end{abstract}


can trigger an increase in volatility accompanied by an increase in risk that occurs, so that investors discourage their investment and have an impact on the decrease in the Composite Stock Price Index (IHSG) (Nida and Pangestuti 2015). With the uncertainty that occurs, a safe haven is needed to avoid the uncertainty and risks that will occur. Baur and Lucey (2010), Robiyanto (2018) said that a safe haven is an asset that is not correlated or negatively correlated with other assets during volatile market conditions.

The development of investment instruments such as gold, silver, palladium, and bonds, has led to many studies examining its potential as a safe haven. The potential of gold as the safest asset has begun to be widely researched, Baur and Lucey (2010) examined the potential of gold for the American, British and German capital markets, while Ghazali, Lean, and Bahari (2013) for the Malaysian capital market. Robiyanto (2018) found that gold can act as a safe haven for the Malaysian capital market. The discovery of gold as a safe haven in several countries, is proof that gold can be the safest asset for some countries. Apart from gold, bonds are also beginning to be studied as a safe haven. Robiyanto (2018) found that bonds can act as a safe haven for the Malaysian capital market,

With the development of various kinds of investment instruments, the financial market gave rise to new instruments in the form of cryptocurrency, especially bitcoin. Third party surveillance is gone and value exchange can be done digitally, cryptocurrencies work on encryption algorithm theory to create unique and limited results (Peter 2016). There are many types of cryptocurrencies to date, such as bitcoin, ripple, litecoin, ethereum, and tether. One of the cryptocurrencies, bitcoin, has a market capitalization value of USD 11.49 billion in 2017 (Yohandi, Trihastuti, and Hartono 2017). The large capitalization of the bitcoin market makes it attractive for investors when the capital market experiences shocks. The potential of cryptocurrency has begun to be studied by researchers from various aspects. Richter, Kraus, and Bouncken (2016) examined cryptocurrency as a paradigm shift in the transaction field. Further 
research was carried out by Peter (2016) regarding the analysis of cryptocurrency, bitcoin in the future. As well as Stensås et al. (2019) examined bitcoin's potential as a safe haven.

Not many studies have simultaneously examined whether gold, bonds and cryptocurrencies can be a safe haven for the stock market. Therefore, this study was conducted to determine whether government bonds, gold and cryptocurrencies can be a safe haven for the Indonesian capital market. The benefit of this research is to assist investors in making decisions when the Indonesian capital market experiences shocks. For academics, this paper is expected to become a basis for related research.

As a refuge, safe havens are assets with low market risk and high liquidity, so they can be used when investors are in doubt about market conditions (Flavin, Morley, and Panopoulou 2014). Meanwhile Baur and Lucey (2010) define a safe haven more quantitatively, by stating that a safe haven is an asset that has a zero or negative correlation with other assets during periods of market turmoil. The occurrence of capital market turmoil not only gave rise to safe haven assets but also hedging assets. The next asset is the diversifier, when both safe haven and hedging cannot be fulfilled, diversifier assets can be a solution, this is because the assets that are spread are more and more and the risk is also spreading.

\section{RESEARCH METHODS}

This study uses secondary data sources, for data on the Composite Stock Price Index (IHSG), bitcoin (BTC) and gold (GOLDIDR) can be downloaded at id.investing.com, for ripple data (XRP), and ethereum (ETH) via www. finance.yahoo.com, while the bond index uses the Indonesia Government Bond Index (IGBI) can be downloaded at https://us.spindices.com. The reason for using BTC, XRP, ETH in this study is because these cryptocurrencies are the cryptocurrencies with the largest market capitalization in the world (id.investing.com). 
This research is a quantitative study using time series data from August 2015 to December 2018 using the Composite Stock Price (IHSG), including the three cryptocurrencies with the largest market capitalizations such as bitcoin (BTC), ripple (XRP), ethereum (ETH), In addition, the Indonesia Government Bond Index (IGBI) and gold (GOLDIDR) are also investigated for their potential in this study.

The explanation of the definition of operational variables used in this study is as follows. The Indonesian capital market is represented by the IHSG, while the return on the $\mathrm{JCI}$ is calculated by the following formula:

$R_{I H S G t}=\left[\frac{I H S G_{t}-I H S G_{t-1}}{I H S G_{t-1}}\right]$

Where:

IHSGt $=$ IHSG closing price for the Indonesia Stock Exchange on day $\mathrm{t}$

IHSGt $-1=$ closing price for the Indonesia Stock Exchange on day $\mathrm{t}-1$

Return cryptocurrency calculated from the return of BTC, XRP, ETH, by applying the following formula:

$R_{\text {cryptocurrencyt }}=\frac{P t-p_{t-1}}{P t-1}$
Where,

$P t=$ The closing price for day $t$, cryptocurrencies, using BTC, XRP, and $\mathrm{ETH}$, respectively.

Pt-1 = The closing price for day $t-1$, cryptocurrencies, using $\mathrm{BTC}, \mathrm{XRP}$, and ETH, respectively.

The return on Indonesian government bonds is calculated from the return on the Indonesia Government Bond Index (IGBI) by applying the following formula:

$R_{I G B I t}\left[\frac{\mathrm{IGBI}_{t}-\mathrm{IGBI}_{t-1}}{\mathrm{IGBI}_{t-1}}\right]$

Where:

$\mathrm{IGBI}_{t}=$ The closing price of the Indonesia Government Bond Index (IGBI) on day $t$ $\mathrm{IGBI}_{t-1}=$ The closing price of the Indonesia Government Bond Index (IGBI) on day $\mathrm{t}-1$

The return of gold per gram in Rupiah (GOLDIDR) is calculated by converting the world gold price per troy ounce in US Dollars into Rupiah prices following the exchange rate of the United States Dollar to Rupiah (USDIDR). The calculation is carried out as follows:

$G O L D I D R=03\left(G O L D_{t} * U S D I D R_{t}\right) / 31.1$ 
The return of gold per gram in Rupiah is carried out using the formula:

$R_{G O L D I D R t}=\left[\frac{G O L D I D R_{t}-G_{O L L I D R_{t-1}}}{G O L D I D R_{t-1}}\right]$

Where,

$G O L D I D R_{t}=$ the closing price of gold per gram in Rupiah on day $\mathrm{t}$

GOLDIDR $_{t-1}=$ closing price of gold per gram in Rupiah on day $\mathrm{t}-1$

This study uses the Ordinary Least Square (OLS) method. This OLS analysis is applied using all daily data periods, and looks at the potential of BTC, XRP, ETH, GOLDIDR, and IGBI as a hedge.

The OLS equation used is as follows:

$R_{\text {Instrumen }, t}=\alpha+\beta_{1} R_{\text {Indeks }}+\varepsilon_{t}$

With:

$\varepsilon_{t}=$ residual term

$R_{\text {Instrumen },}=$ return $\mathrm{BTC}, \mathrm{XRP}, \mathrm{ETH}$, GOLDIDR, and IGBI

$R_{\text {Indeks }}=\mathrm{JCI}$ return

In this OLS formula, if it does not have a significant effect, then bitcoin, ethereum, ripple, gold and bonds can be hedged as long as shocks occur in the Indonesian capital market, this is in line with
$R_{\text {Indeks }}$ Baur and Lucey (2010) and Robiyanto (2018) in previous research.

To test whether BTC, XRP, ETH, GOLDIDR, and IGBI can act as a safe haven for the Indonesian capital market, data analysis is also performed using Quantile Regression (QREG).

$R_{\text {Instruiment }, t}=\alpha+$

$\beta_{1} R_{I H S G(Q 50 \%, 40 \%, 30 \%, 20 \%, 10 \%)}+\varepsilon_{t}$

With,

$\varepsilon_{t} \quad=$ residual term

$R_{\text {Instrument }, t}=$ return $\mathrm{BTC}, \mathrm{XRP}$ and $\mathrm{ETH}$. $R_{I H S G}=$ return in the JCI for $\mathrm{Q} 50$ percent, 40 percent, 30 percent, 20 percent and 10 percent.

Quantile Regression (QREG) techniques are commonly applied, especially in research on safe haven instruments (Robiyanto, 2018). Using QREG can provide the instrument with sensitivity and resilience to adverse market conditions. By using the QREG formula, if not significant then $R_{\text {indeks }} \mathrm{BTC}, \mathrm{XRP}, \mathrm{ETH}$, GOLDIDR, and IGBI can be a safe haven for the Indonesian capital market, this is in line with Baur and Lucey (2010), Robiyanto (2018) in previous research. 


\section{RESULTS AND DISCUSSION}

The Unit Root Test in this study used Augemented Dickey Fuller (ADF). It can be seen in Table 1 that there is no unit root and the data in this study is stationary, so it can be analyzed using the Ordinary Least Square (OLS) method and the Quantile Regression (QREG) technique.

The results of the Ordinary Least Square (OLS) and Quantile Regression (QREG) analysis can be seen in Table 2. Table 2 shows that bitcoin (BTC) is not a safe asset for the Indonesian capital market. In addition, based on the OLS analysis, bitcoin is only able to be a diversifier, because it has an insignificant positive sign. It can be seen in the results of the QREG analysis of 50 to 20 percent, all of which have positive and insignificant signs. In the 10 percent quantile bitcoin starts following the movement of the stock market by showing a positive sign with a significance level of 5 percent. This shows that in the deteriorating capital market conditions, bitcoin will follow market movements.
In general, the OLS and QREG results show that bitcoin is not a safe haven for the Indonesian capital market. The OLS ripple (XRP) analysis also shows that XRP is only able to be a diversifier for the Indonesian capital market, because it has an insignificant positive sign. 
Table 1. Unit Root Test Results from the Returns of the IHSG, BTC, XRP, ETH, GOLDIDR, and IGBI on 07 August 2015 - 28 December 2018

\begin{tabular}{cccc}
\hline Variable Name & t-Statistic & Probability & Result \\
\hline JCI & -27.29675 & 0.0000 & Stationary \\
BTC & $-35,49380$ & 0.0000 & Stationary \\
XRP & -11.09976 & 0.0000 & Stationary \\
ETH & -28.64604 & 0.0000 & Stationary \\
GOLDIDR & -27.07905 & 0.0000 & Stationary \\
IGBI & $-19,63267$ & 0.0000 & Stationary \\
\hline
\end{tabular}

Table 2. Results of analysis of BTC, XRP, ETH, GOLDIDR, and IGBI on QREG and OLS

\begin{tabular}{ccccccc}
\hline & & \multicolumn{5}{c}{ Quantile } \\
\cline { 3 - 7 } & OLS & $\mathbf{0 . 5}$ & $\mathbf{0 . 4}$ & $\mathbf{0 . 3}$ & $\mathbf{0 . 2}$ & $\mathbf{0 . 1}$ \\
\hline BTC & & & & & \\
C & 0.000326 & 0.000751 & -0.001095 & -0.003164 & -0.005637 & -0.009928 \\
& $(0.992508)$ & $(2,470892)$ & $(-3.289952)$ & $(-8.705937)$ & $(-13,45695)$ & $(-14,45899)$ \\
JCI & 0.003252 & 0.002749 & 0.002895 & 0.000826 & 0.001201 & $0.014439 * *$ \\
& $(0.607673)$ & $(0.812703)$ & $(0.967971)$ & $(0.310112)$ & $(0.218736)$ & $(1.772735)$ \\
\hline XRP & & & & \\
C & 0.000312 & 0.000648 & -0.001079 & -0.003202 & -0.005693 & -0.009573 \\
& $(0.945877)$ & $(2,068031)$ & $(-3.226728)$ & $(-8.752580)$ & $(-13,38055)$ & $(-15,31084)$ \\
JCI & 0.004574 & $0.005638 * *$ & $0.006912 * *$ & $0.009159 * * *$ & $0.008422 *$ & $0.0142411^{* * *}$ \\
& $(1,521630)$ & $(1.866760)$ & $(2,085545)$ & $(2.683246)$ & $(1,807443)$ & $(2,760868)$ \\
\hline ETH & & & & & \\
C & 0.000352 & 0.000825 & -0.001133 & -0.003162 & -0.005681 & -0.009761 \\
& $(1.064528)$ & $(2,629801)$ & $(-3,298604)$ & $(-8,587540)$ & $(-13,51136)$ & $(-15,39643)$ \\
JCI & 0.000617 & -0.000399 & 0.003021 & 0.003502 & 0.003121 & $0.007791 *$ \\
& $(0.183513)$ & $(-0.107491)$ & $(0.741861)$ & $(0.839297)$ & $(0.898831)$ & $(1,765562)$ \\
\hline GOLDID & & & & & \\
R & & & & & \\
C & 0.000336 & 0.000799 & -0.001058 & -0.003220 & -0.005599 & -0.009728 \\
& $(1,024236)$ & $(2.622015)$ & $(-3.151032)$ & $(-8,838657)$ & $(-13.64238)$ & $(-13,60550)$ \\
JCI & $0.074800 * *$ & 0.028577 & 0.04346 & 0.024993 & 0.013807 & 0.050910 \\
& $(2,217364)$ & $(0.874552)$ & $(1.084099)$ & $(0.565581)$ & $(0.273134)$ & $(0.924146)$ \\
\hline IGBI & & & & & \\
C & 0.0000181 & 0.000551 & -0.001375 & -0.003298 & -0.005558 & -0.011344 \\
& $(0.057976)$ & $(1.776430)$ & $(-4.188884)$ & $(-9,409445)$ & $(-12.54334)$ & $(-12.89349)$ \\
JCI & $0.947052 * * *$ & $0.707261 * * *$ & $0.750994 * * *$ & $0.690753 * * *$ & $0.735762 * * *$ & $0.962093 * * * *$ \\
& $(9,934183)$ & $(5,297234)$ & $(5,560002)$ & $(4.663860)$ & $(3,427181)$ & $(5,905321)$ \\
\hline
\end{tabular}

Self-processed secondary data sources

Information: Numbers in parentheses are t-statistics

* significant at the $10 \%$ significance level; ** significant at the $5 \%$ significance level; *** significant at the $1 \%$ significance level 
In Table 2, it can be seen that the results of the QREG analysis show that ripple cannot be a safe haven for the Indonesian capital market at a condition of 50 to 10 percent, because the regression coefficient is significant positive. At 50 to 40 percent conditions, ripple has a positive sign with a significance level of 5 percent, and conditions 30 and 10 percent show a positive regression coefficient sign with a significance level of 1 percent. Furthermore, at 20 percent the ripple regression coefficient shows a positive sign with a significance level of 10 percent. No different from other cryptocurrencies, the results of OLS carried out on ethereum (ETH) show an insignificant positive sign, this causes ethereum to act as a diversifier for the Indonesian capital market.

The QREG analysis conducted for ethereum shows that when the 50 percent quantile has a negative regression coefficient, it is not significant, which means that in this condition ethereum can act as a safe haven. However, in the 40 to 20 percent quantile the coefficient was positive and insignificant. Even in the worsening condition represented by the 10 percent quantile, ethereum produced a significant positive coefficient. Overall, it can be said that ethereum, in the 50 percent quintile, can be a safe haven. However, at a time when market conditions became more extreme, ethereum followed the movement of the Indonesian capital market. In general, the results of this study indicate that cryptocurrency bitcoin, ripple, and ethereum cannot be a hedge and safe haven for the Indonesian capital market..

The results of the analysis for gold instruments (GOLDIDR) using OLS show a positive regression coefficient with a significance level of 5 percent, this shows that gold cannot be a hedge. Subsequent findings on gold with an overall QREG analysis of 50 to 10 percent quantile yielded insignificant positive regression coefficients. This shows that gold cannot act as a safe haven for the Indonesian capital market. These findings are in line with 
researchBaur and Lucey (2010) in America as well Robiyanto (2018) in Indonesia

OLS analysis results on bonds Indonesia Government Bond Index(IGBI) shows that the positive regression coefficient is not significant, this makes bonds a diversifier for the Indonesian capital market. Furthermore, the QREG analysis conducted shows that bonds cannot be a safe haven for the Indonesian capital market. This is because the 50 to 10 percent quantile of bonds produces a positive regression coefficient with a significance level of 1 percent. Kinability Indonesia Government Bond Index (IGBI) being a safe haven for the Indonesian capital market is supported and in line with the findings Robiyanto (2018).

\section{CONCLUSION}

This study found that the cryptocurrencies under study, namely bitcoin, ripple, and ethereum, cannot be a strong safe haven for the Indonesian capital market. This research also found that bitcoin, ripple, and ethereum were also unable to hedge, but bitcoin, ripple and ethereum could serve as diversifiers for the Indonesian capital market.

Gold (GOLDIDR) cannot be a safe haven or hedge, but gold has the ability to be a diversifier for the Indonesian capital market. Furthermore, this study also found thatIndonesia Government Bond Index (IGBI) cannot act as a safe haven, hedge or as an asset diversifier.

This study uses daily data for an observation period of three and a half years, so future research is highly recommended to add a longer daily data period even if research is needed in times of instability such as the Covid-19 pandemic era. Cryptocurrencies used during this research, namely bitcoin, ripple, and ethereum, are the 3 cryptocurrencies with the largest market cap. Future research is suggested to add to other cryptocurrencies such as tether and litecoin.

This research is still conducting a limited study of the Indonesia Government Bond Index (IGBI). Future research can use the Indonesia 
Financials Bond Index (IFBI) and the Indonesia Corporate Bond Index (ICBI) to research.

\section{REFERENCE}

Baur, D. G., \& Lucey, B. M. (2010). Is gold a hedge or a safe haven? an analysis of stock, bond and gold. The Financial Review, 45(3), 217-229.

Flavin, T. J., Morley, C. E., \& Panopoulou, E. (2014). Identifying safe haven assets for equity investor through an analysis of the stability of shock transmission. Journal of International Financial Markets, Institutions and Money, 33, 137-154. https://doi.org/10.1016/j.intfin.20 14.08.001

Ghazali, M. F., Lean, H., \& Bahari, Z. (2013). Is gold a hedge or a safe haven? an empirical evidence of gold and stocks in Malaysia. International Journal of Business and Society, 14(3), 428-443.

Nida, F., \& Pangestuti, I. R. D. (2015). Analisis pengaruh perilaku herding investor asing, volatilitas Indeks Harga Saham Gabungan, tingkat inflasi, dan kapitalisasi pasar terhadap return pasar. 4, 1-11.

Peter, DeVries. (2016). An analysis of cryptocurrency, bitcoin, and the future. International Journal of Business Management and Commerce, 1(2), 1-9. Retrieved from https://www.researchgate.net/pu blication/316656878_An_Analysis_ of_Cryptocurrency_Bitcoin_and_th
e_Future

Richter, C., Kraus, S., \& Bouncken, R. B. (2016). Virtual currencies like bitcoin as A paradigm shift in the field of transactions. International Business \& Economics Research Journal, 14(4), 575-586. https://doi.org/10.19030/iber.v14i 4.9350

Robiyanto, R. (2018). Gold vs bonds: what is the safe haven for the indonesian and Malaysian capital market? Gadjah Mada International Journal of Business, 20(3), 277-302. https://doi.org/10.22146/gamaijb. 27775

Stensås, A., Nygaard, M. F., Kyaw, K., \& Treepongkaruna, S. (2019). Can Bitcoin be a diversifier, hedge or safe haven tool? Cogent Economics and Finance, 7(1), 1-17. https://doi.org/10.1080/23322039. 2019.1593072

Yohandi, A., Trihastuti, N., \& Hartono, D. (2017). Implikasi yuridis penggunaan mata uang virtual bitcoin sebagai alat pembayaran dalam transaksi komersial (studi komparasi antara IndonesiaSingapura). Diponegoro Law Jurnal, 6(2), 1-19. https://doi.org/10.1017/S02698889 07001014 